\title{
Research nurses contributions to research practice: an oncology nursing experience in Brazil
}

Bruna Tirapelli* ${ }^{*}$, Silvana Soares dos Santos, Bruna Elisa Catin Kupper and Amanda Aparecida França de Nobrega

\begin{abstract}
Background: The creation and evolution of research nurse, connected with some specialty, brings a new path to be covered and structured inside nursering. The position of Researcher Nurse was initially created decentralized only one Department. In past the years and after the role of work was being consolidating. This paper describes the creations and evolution of Research Nurses in the scene an Oncology Research Practice at a Cancer Center.

Methods: Behind of a timeline description the information that in 10 years give us the number of participant departments increased, with an increase of the scientific production, besides the construction of the position of Research Nurses.

Results: Throughout these years, integration and interdepartmental action were developed, with a role and seat in Biobanco, Ethics Committee in Research, Operative Systems of medical Informatics, as well as participation in multicentric, institutional projects within the Brazilian and world Oncology.

Conclusions: The role of Research Nurses being a facilitator for the development of Research Center and consequently scientific institutional progress.
\end{abstract}

Keywords: Research center, Oncology, Nurses

\section{Background}

Oncology has been practiced through the breakdown of paradigms provided by scientific studies in the various spheres of knowledge and with this bringing an impact in the way of diagnosing and treating the individual affected by a chronic disease [1].

The research also generates the basis for the improvement of diagnosis and cure, permeates advances equally in the sphere of pharmacological and non-pharmacological treatment of comorbidities adding to the oncological attention the evidence-based practice, contributing to the increasing of the quality of life of the oncologic patients and decreasing the adoption of ineffective practices [2].

Considering the Brazilian National Politics of Oncology Attention, which the premise is the creation of Specialized Centers to treat persons with cancer, the assistance comes together with teaching and research to

\footnotetext{
* Correspondence: bruna.goncalves@accamargo.org.br International Research Center-CIPE /AC Camargo Cancer Center, 440, Tagua st - Postal Code, Sao Paulo 01508-010, Brazil
}

achieve excellence and improvements in the treatment of oncologic patients [3].

The Researcher's role, involving research in humans, in the Specialized Centers focuses on health promotion and the implementation of new health care systems. It is also worth mentioning the responsibility in conducting research in the conduct of research that shares and translates values based on: honesty, accuracy, efficiency and objectivity [4].

Nurses are the professional whose main competence in providing the integral care to individuals, family and society, stands out as a factor of integration between care, the driving force of their work and the development of science, a factor stimulated and predicted in their professional skills that has been consolidating over the years in the national and international scientific community $[5,6]$.

Aiming to achieve the specific behavioral competences in the research area, research nurses should be proactive and curious expressing flexibility of changes and 
interpersonal relationships. The previous criteria are already described as generic skills [7] of the Nurse, thus bringing greater proximity between the job and the professional requirements.

The scope of the work developed by Researcher Nurses is quite broad, focusing on observational, translational and clinical trials in the various areas of knowledge of Health Sciences linked to a project belonging to a Researcher of the Institution. As a working element the development of database, tracking, recruitment and monitoring of patients selected for research that are under development in the institution in the various departments of specialty Oncology.

The construction of this paper is justified by the need to make known the form of composition of a position / function where a Nurse exercises his professional competences aimed at the practice of Research in different spheres of scientific knowledge in a Cancer Center.

The present study aims to demonstrate the of the position of Nurse focused on the practice of research in a Cancer Center.

\section{Methods}

It is a descriptive study about the exercise of the role of a Research Nurses at a Cancer Center.

The productivity report was outlined with the scores of works of the Nurse Researchers by the institutional software for data input, called XUSD ${ }^{\circ}$ (Extensible Unified System Data). After one year of use, it has been avaliated, reformulated and is currently an important tool for monthly / annual evaluation of the results.

General Information includes the personal identification, date (month / year) of the professional registration and vacation warning. This record is stored in the program and can be accessed by the management and / or professional at the time it is necessary, fot this the person need to have access permission to this form.

They are considered to be evaluative in their production, demonstrating their scope of work in the practice and development of observational, and translation studies, as well as Non-sponsored clinical trials performed institutionally.

These indicators are part of a report that is monthly filled for each nurse, on a fixed, pre-determined date. The fill occurs digitally with login from the institutional software for data input, called XUSD ${ }^{\circ}$ (Extensible Unified System Data). This data management system was created and managed by the Department of Medical Informatics of the International Center of Research - CIPE - A.C.Camargo Cancer Center. It generates monthly an individual analysis of the production of each nurse to the coordinator, that evaluates the individual development and consequently of the group as a whole.

The information to be filled in the report are related to general information of professional identification, $\mathrm{XUSD}^{\circ}$ Databases and not XUSD ${ }^{\circ}$ TCLE (Consent Free and Informed Consent) of Biobank and other projects, Collection and follow-up of future collections of biological material, Patient Management, Research Ethics and Disclosure of research data.

Ethical precepts were respected in the presentation of data, without being required to submit to the Ethics Committee because it is an experience report.

\section{Results}

\section{The construction of the position of research nurse}

Initially the research nurses, were linked to the different medical department of the hospital, in order to create the institutional databases and assure the recording of the information. With the expansion of the national and international research projects at the institution, the procedures necessary to the development for the researches were also added to the position of the research nurse.

Table 1 shows the growth and change of function for job creation between 2001 and 2017.

\section{Productivity}

Based on the analysis performed through indicators of productivity, behind the institutional software for data input there was an overall growth of 8,56 times in the production of research nurses based on the last two years.

The Fig. 1 illustrates a schematic of the indicators that were constructed through the job demand and the description of the functions of the Nurse Researchers and all topics that represent the function of Research Nursing.

The topic on Databases is divided into two items, $\mathrm{XUSD}^{\circ}$ and non-XUSD ${ }^{\circ}$ banks. $\mathrm{XUSD}^{\circ}$ bank is understood to be the banks that are created to collect the data in the $\mathrm{XUSD}^{\circ}$ platform, being stored there and generating Excell spreadsheet for statistics when necessary, which is the model prioritized for the creation and retention of institutional data. XUSD ${ }^{\circ}$ banks created and

Table 1 The Position / function Nurse Researcher over time

\begin{tabular}{lllllll}
\hline Year & 2001 & 2004 & 2008 & 2011 & 2013 & 2015 \\
\hline Function & Nurses with research functions & Research Nurses & & & \\
Number of nurses & 02 & 03 & 05 & 05 & 08 & 12 \\
\hline
\end{tabular}




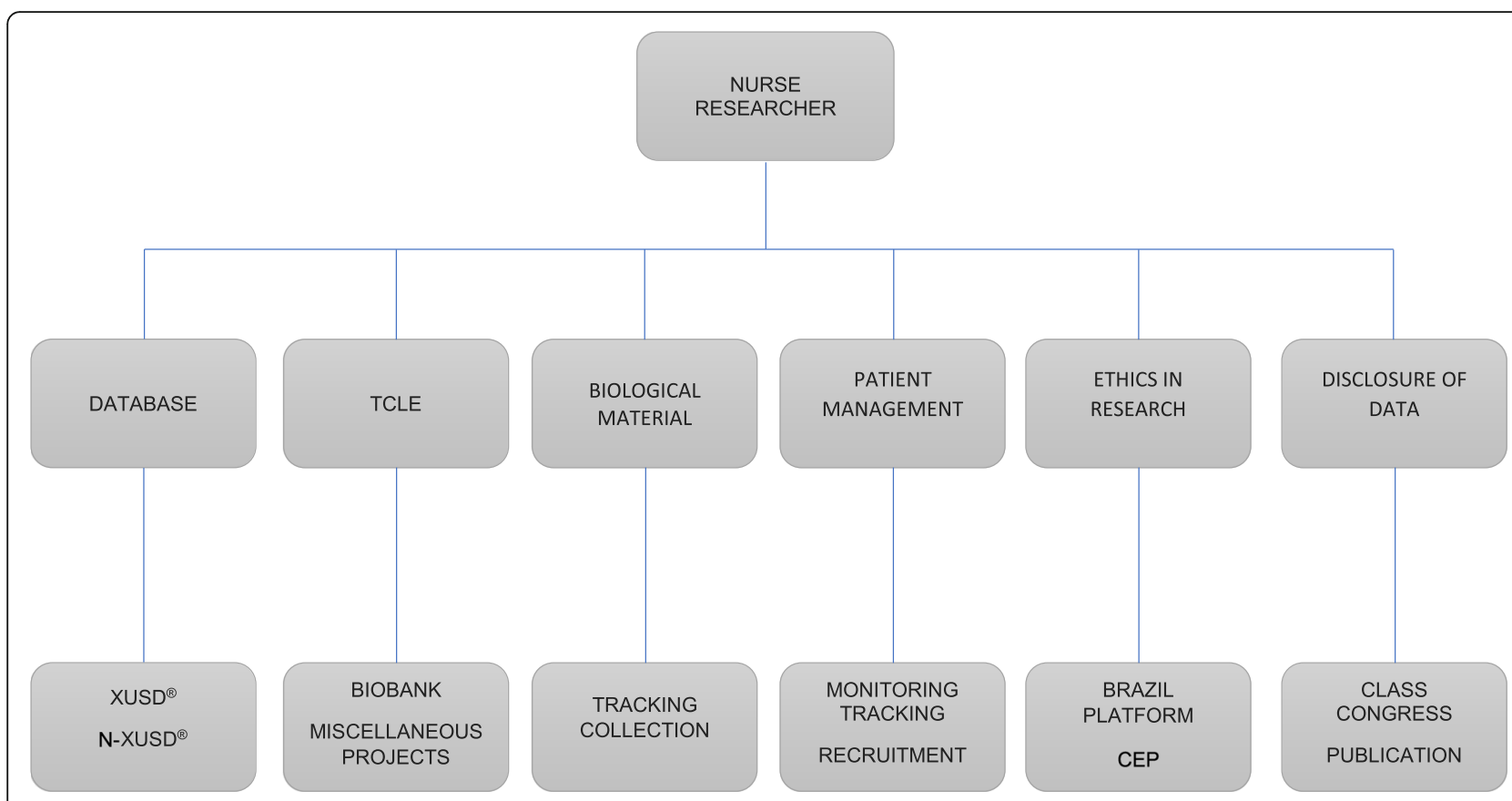

Fig. 1 Scheme of the Production Indicators of Nurse Reseachers. TCLE: Free and Informed Consent Form; XUSD ${ }^{\circledR}$ : Extensible Unified System Data; N-XUSD ${ }^{\oplus}$ : No XUSD; ${ }^{\oplus}$ CEP: Research Ethics Committee

fed already derive direct accounting from the report of the nurse who did so, since the system is the same. Non-XUSD ${ }^{\circ}$ banks are banks that eventually are created or already exist and are performed for data statistics, such as banks in Excell, SPSS, REdCap, Stata. They are indicators of production of Database: counted creation of new banks, banks with more than 5 variables; Updating data of patients already belonging to a bank, including a patient for the first time in an existing bank.

The TCLEs are applied to all patients exposed to research involving human as mandatory procedure in scientific practice [8]. The Nursing Researchers have as a work demand the application of the TCLEs to the entry of the individual in the current study and also the application of the TCLEs to the patient with biobank material that need reconsideration, each application is counted, generating the data of how many terms are applied, Consented or refused.

Collections of biological material from individuals involved in institutional research projects, are also part of their work routine. The Nurse Researcher coordinates the collection times, the communication with the patient, the collection team, the processing and storage of the samples, as well as their transportation. Work processes are developed between the Laboratory of Clinical Analyzes, Laboratories of Basic Research, Clinical Departments, Surgical and Diagnostics of the Institution, so that this collection occurs in an ethical and safe way.

In the Patient Management indicator, the entire working time with the individual's search, entry and maintenance of the research is grouped: a Scheduling monitoring for possible research members; Tracking of data, queries, returns, for the coordination of the exact moment to present to the individuals applying inclusion criteria for the different studies targeted by the research; Prospective recruitment, which is when the individual is recruited so that it is part of the research that will be developed.

As in any scientific research process,institution review board analysis is the first step for the project being conducted, and the research nurse is the responsible for the enrollment of the project in the National and Institutional Research Ethics Platforms. The Ethics in Research indicator counts how many projects are inserted in the Systems of Ethics in Research, being they in "Brazil Plataform", a unified and national system that regulates research practices involving human beings, and the Research Ethics Committee of A.C.Camargo Cancer Center.

All the data generated by research nurses are used for the preparation of classes, articles for publication in national and international journals, and posters presented at Congresses.

Table 2, at the end of the text, shows a descriptive of the actions and the way of assessing productivity of the position over the years.

\section{Discussion}

This study shows the trajectory that Research Nurses on the practice consolidating the professional practice for research activities. 
Table 2 Report of activities of Research Nurses. AC Camargo Cancer Center, São Paulo 2017

\begin{tabular}{|c|c|c|c|c|}
\hline Period & Until February 2013 & $\begin{array}{l}\text { March / } 2013 \text { to } \\
\text { March / } 2015\end{array}$ & From June 2015 to August 2016 & From September / 2016 to current \\
\hline $\begin{array}{l}\text { Systematized } \\
\text { production report }\end{array}$ & There is not & There is not & $\mathrm{XUSD}^{\otimes}$ & $\mathrm{XUSD}^{\oplus}$ \\
\hline Type of information & Not standardized & $\begin{array}{l}\text { Description of activities } \\
\text { as realized }\end{array}$ & $\begin{array}{l}\text { 1. Inclusions / case updates in } \\
\text { XUSD }^{\circledR} \text { Excel } \\
\text { created } \text {, IBM SPSS }{ }^{\oplus} \text {, } \\
\text { 2. Applied TCLEs; } \\
\text { 3. Collection of biological material; } \\
\text { 4. Works included in congresses or } \\
\text { scientific events; } 5 \text {. Works registered } \\
\text { in the Brazil Platform and / or CEP; } \\
\text { 6. Prospective recruitment of patients; } \\
\text { 7. Screening of potential cases for study; } \\
\text { 8. Description of other activities }\end{array}$ & $\begin{array}{l}\text { 1Number of databases created; } \\
\text { 2. Inclusions / case updates in } \\
\text { XUSD } \\
\text { 3.Import data (from Excel }{ }^{\oplus}, \text { IBM SPSS }^{\oplus} \text { ) } \\
\text { to XUSD ; } \\
\text { 4. applied TCLES; } \\
\text { 5. Collection of biological material } \\
\text { in research; } \\
\text { 6. Patient monitoring; } \\
\text { 7.Work included in congresses or } \\
\text { scientific events; } \\
\text { 8. Work registered in the Brazil Platform } \\
\text { and / or CEP; } \\
\text { 9. Prospective recruitment of patients; } \\
\text { 10. Screening of potential cases for study; } \\
\text { 11. Description of other activities. }\end{array}$ \\
\hline Periodicity & Not standardized & Quarterlyl. & Monthly & Monthly \\
\hline Record & Not standardized & $\begin{array}{l}\text { Individual, by } \\
\text { department }\end{array}$ & Individual, by department. & Individual, by department.. \\
\hline
\end{tabular}

XUSD $D^{\oplus}$ Extensible Unified System Data, TCLE Free Informed Consent Term, CEP Research Ethics Committee

In 2008, there was the characterization and creation of the position of Researcher Nurse. The desirable requirements described to attend for the position of Research Nurse were: Experience of 2 to 3 years as a nurse; Academic Background: Superior in Nursing, specialist in Oncology Nursing. To perform research activities, assuring ethics and within the legal precepts in national territory some specific minimum knowledge is expected. [8] It is hopped the knowledge of Good Clinical Practices; Resolutions of the National Health Council / Ministry of Health (CNS / MS); Resolutions of the Collegiate Directorates (RDCs) of the National Agency of Sanitary Surveillance (ANVISA), bioethical aspects of the confidentiality and privacy of the research subjects.

In order to strengthen the capacity of the Nurse Researcher [9] in the field of world science, knowledge of the English language is also required as a basic requirement for the position.

The institutional organization strengthened the link between research and assistance, with great strides to establish itself as an institution delimited by the pillars of assistance, teaching and research and made it possible for the medical departments to have an organization to be composed of research nurses still without a categorization as position, only assuming research functions, but still institutionally linked as a care nurse.

Based on the analysis performed through indicators of productivity, there was an overall growth in the production of research nurses based. This increase in production is reflected directly in the scientific institutional production and consequently in the scenario of national and international Oncology.

\section{Conclusions}

The creation and evolution of the Research Nurse career linked to an area and participant in several Sciences of the area of Health brings a new way to be covered and structured, within the nurse profession and the specialty. Positions such as these can facilitate the development of Research Centers and consequently scientific institutional progress.

\section{Abbreviations}

ANVISA: National Health Surveillance Agency; CEP: Research Ethics Committee; CIPE: International Research Center; CNS/MS: National Health Council / Ministry of Health; N-XUSD ${ }^{\oplus}$ : No XUSD ${ }^{\oplus}$; RDCs: Resolutions of the Collegiate Boards; TCLE: Consent Form Free and Informed; XUSD ${ }^{\oplus}$ : Extensible Unified System Data

\section{Acknowledgements}

Not applicable.

Funding

Not applicable.

Availability of data and materials

Not applicable.

\section{Authors' contributions}

BT been involved in drafting and writing the manuscript SS and AFN acquisition of data, and analysis and interpretation of data and made substantial contributions to conception and BC revising it critically for important intellectual content. All authors read and approved the final manuscript.

Ethics approval and consent to participate Not applicable.

\section{Consent for publication}

Not applicable.

Competing interests

The authors declare that they have no competing interests. 


\section{Publisher's Note}

Springer Nature remains neutral with regard to jurisdictional claims in published maps and institutional affiliations.

Received: 4 August 2017 Accepted: 7 December 2017

Published online: 04 January 2018

\section{References}

1. Kovvali G. Systems oncology: a new paradigm in cancer research. J Carcinog. 2014;13:6.

2. Johnson LA. Putting evidence into practice. Clin J Oncol Nurs. 2014; 18(Suppl):2-4.

3. Moreira MC, Carvalho V, Silva MM, Sanhudo NF, Filqueira MB. Produção de conhecimento na enfermagem em oncologia:contribuição da escola de enfermagem Anna Nery. Esc Anna Nery. 2010;14:575-84.

4. Steneck NH. Introduction to the responsible conduct of research. 2007. https://ori.hhs.gov/sites/default/files/rcrintro.pdf. Accessed 20 May 2017.

5. Salles EB, Barreira IA. Formação da comunidade científica de enfermagem no Brasil. Texto Contexto Enferm, Florianópolis. 2010;19:137-46.

6. Knobf MT, Cooley ME, Duffy S, Doorenbos A, Eaton L, Given B, et al. The 2014-2018 Oncology Nursing Society research agenda. Oncol Nurs Forum. 2015:42:450-65.

7. Melo RCCP, Silva MJP, Parreira PMD, Ferreira MMC. Competências Relacionais de Ajuda nos enfermeiros: validação de um instrumento de medida. Rev Esc Enferm USP. 2011:45:1387-95.

8. Fundação de Amparo à Pesquisa do Estado de São Paulo (FAPESP). Código de boas práticas Científicas, 2014. http://www.fapesp.br/boaspraticas/ FAPESP-Codigo_de_Boas_Praticas_Cientificas_2014.pdf (2014). Accessed 12 July 2017.

9. Erdmann AL. A necessidade de atingirmos novos patamares na pesquisa de enfermagem-editorial. Acta Paul Enferm 2009;22:v-vi.

Submit your next manuscript to BioMed Central and we will help you at every step:

- We accept pre-submission inquiries

- Our selector tool helps you to find the most relevant journal

- We provide round the clock customer support

- Convenient online submission

- Thorough peer review

- Inclusion in PubMed and all major indexing services

- Maximum visibility for your research

Submit your manuscript at www.biomedcentral.com/submit 